\title{
Effective instructional design for web-based English vocabulary learning: Under the light of theories ${ }^{1}$
}

\author{
Dinçer Biçer ${ }^{2}$ \\ Ömür Akdemir ${ }^{3}$
}

\begin{abstract}
There has been exciting and serious progress in the field of computers for teaching English. Identification of the most effective methods is essential to make teaching and learning more efficient. The purpose of this study is to investigate the effects of using multiple content forms in web-based instruction on students' English vocabulary learning. The study was conducted at the Compulsory Preparatory Program of a state university located in the Black Sea region of Turkey with 106 students. The factorial research design was used to conduct the study. Thus, the effect of using multiple content forms in web-based instruction on students' English vocabulary learning was analyzed. The vocabulary level of students was measured with a web-based multiple choice English vocabulary achievement test. The measure of internal consistency of the English vocabulary achievement test was 0.966 . The findings of this study indicate that, in vocabulary teaching, providing definitions in an audio format in English is more effective in teaching English vocabulary than providing the same definitions in an audio format in English accompanied with pictures. Mobile devices which eliminate the time and distance limitations can be used in further studies with developmental applications to investigate the effects on students' English vocabulary learning.
\end{abstract}

Keywords: Web-based instruction; Foreign language learning; Vocabulary learning; Educational technology; Higher education

\section{Introduction}

In today's developing world, information has become more important than ever before. Accessing information, most of the time, requires reading comprehension skill. Such sources of information as the Internet, libraries and articles can meet individuals' information requirements.

\footnotetext{
1 This study was completed as a master thesis under the supervision of Asoc. Prof. Ömür Akdemir by Dinçer Biçer.

2 Instructor and a graduate student at the Bülent Ecevit University, Bulent Ecevit University, Turkey. E-mail address: dincer.bicer@gmail.com

${ }^{3}$ Associate Professor at the Computer Education and Instructional Technology Department, Bulent Ecevit University, Turkey. E-mail address: omurakdemir@gmail.com
} 
Biçer, D., Akdemir, Ö. (2015). Effective instructional design for web-based English vocabulary learning: Under the light of theories. International Journal of Human Sciences, 12(1), 1463-1476. doi: 10.14687/ijhs.v12i1.3204

However, majority of current information is written in English. According to Türkyllmaz (2008), foreign language education has existed for quite a long time and it is currently continuing its mission of transferring culture. As Simsek, Özdamar, Becit, Kılıçer, Akbulut \& Yıldım (2007) state, education has the most important role in keeping up with the requirements of the century and catching up with progress, and for this role to be fulfilled, it is necessary to benefit from technology efficiently in education.

In the $21^{\text {st }}$ century, one of the most widely-used and effective means of technology used in education is undoubtedly computers. Computers and computer technologies, unlike radio and television, are in a process of constant change and progress (Iandoli, 1990). One of the improvements in computer technologies is the connection of computers to each other via networks. Indisputably, the largest of these networks is the World Wide Web, known as the Internet. The easiness of accessing internet connections, the decrease in cost whereas the speed is increasing has enabled the widespread use of the internet in many fields along with foreign language learning. The Internet and computer technology have altered the education landscape (Akdemir, 2008). With the widespread use of computers and World Wide Web in the field of education, a new term called Computer Assisted Language Learning (CALL) has emerged. CALL eliminates the time and space limitation of conventional education and removes boundaries of schools and classrooms, making learning possible everywhere and every time.

Web-based Language Learning is becoming a main component of Computer Assisted Language Learning (CALL). As Hamatr (2008) states, the use of the internet and computer networks for the purpose of learning and teaching foreign languages has become more widespread since the improvement in computer networks at the beginning of the 1990s. Besides, a number of technologies have been developed for the purpose of language learning since then. According to Karal and Berigel (2007), with the improvement in web technologies, considerable improvements have taken place in the use of web-based educational tools in educational environments in the past few years. Moreover, Hismanoglu (2010) states that internet has recently become one of the most widespread educational tools and has been incorporated in the field of education in order to make foreign language learners enthusiastic to learn.

The ability of students to access the teaching material anytime and anyplace they want and easiness of use has recently added to the popularity of web-based Language Learning. As Ying Ping (2008) states, vast amounts of information on the internet can be accessed rapidly with no cost from everywhere by everyone as long as they can access the internet. According to Hismanoglu 
Biçer, D., Akdemir, Ö. (2015). Effective instructional design for web-based English vocabulary learning: Under the light of theories. International Journal of Human Sciences, 12(1), 1463-1476. doi: 10.14687/ijhs.v12i1.3204

(2010), another important quality of web-based Language Learning is the support for listening and reading skills in audible and visible formats and its being a vast source of original material.

According to Zhang (2009), web-based Language Learning enables the use of a number of techniques which can not be applied in books and printed formats. Among these, there is the use of rich visual elements such as videos and their presentation to students blended with many other elements in various formats. Karal and Berigel (2007) emphasize that web-based learning environments are a significant source of materials for effective foreign language learning. Furthermore, Hismanoglu (2010) states that internet can help altering traditional teaching methods to more modern ones when incorporated in learning and teaching properly.

Karal and Berigel (2007) point out that the advances in the web-based foreign language learning are exciting and they are in a process of considerable improvement. The information to be used in the web-based learning environment is present in the internet. Wood (2001) summarizes the rich components of web-based language learning as follows:

1. Animations,

2. Audible components,

3. Hints for the meaning of vocabulary,

4. Presentation of the given information in various formats and

5. Online definitions, dictionaries and word lists

The use of these mentioned components in computer media and their adaptation to webbased environment are quite simple. Sarıca and Çavus (2010) emphasized that a number of main language skills can be improved with web-based language learning activities and four main skills, listening, speaking, writing and reading can be made interactive in various ways by presenting in the web format.

Learning vocabulary is the fundamental step to learn a foreign language (Basoglu \& Akdemir, 2010). However, unless the correct techniques are applied, vocabulary learning can be difficult and boring for students. Computers can be used to make vocabulary learning easier and make it entertaining for students. Vocabulary teaching has always been a popular subject in CALL. As Ma and Kelly (2006) indicate, vocabulary teaching could be integrated in CALL software easily especially in 1980s when technology was rather simple and currently, vocabulary learning is usually considered as a sub-component of a multimedia package or CALL software. 
Biçer, D., Akdemir, Ö. (2015). Effective instructional design for web-based English vocabulary learning: Under the light of theories. International Journal of Human Sciences, 12(1), 1463-1476. doi: 10.14687/ijhs.v12i1.3204

Vocabulary teaching can be conducted in various ways using many different components of multimedia packages as listed by Wood (2001) above. Web-based language learning technologies can present the content in multiple ways, letting students choose among vocabulary teaching lessons in which the content is presented in different ways. Providing options is a positive side of web-based language learning. According to Ma and Kelly (2006), it is important that students are granted as much freedom as possible to choose what and how to learn. However, providing options can present a problem if the students do not know how to do the activities and how to use the software. In sum, granting too much freedom to novice computer users can lead to negative learning consequences.

A significant issue in web-based language learning is the decision on the components of the online material. The presence of multiple components can make the decision process even harder for instructors and material developers. The Dual Coding Theory is an important theory which sheds light on this issue (Paivio, 1971). As Paivio (1990) states, the theory is based on the general view that cognition consists of the activity of symbolic representational systems that are specialized for dealing with environmental information in a manner that serves functional or adaptive behavioral goals. According to Paivio (1990), there are two classes of phenomena handled cognitively by separate subsystems, one specialized for the representation and processing of information concerning nonverbal objects and events, the other specialized for dealing with language. As explained in the theory, Paivio (1990) emphasizes that these two subsystems are independent in the sense that either system can be active without the other or both can be active in parallel, and at the same time, they are functionally interconnected so that activity in one system can initiate activity in the other.

According to Paivio and Csapo (1973), remembering the information presented in the form of pictures is easier than information presented in written words. This can be explained by the complexity level of written information and the superiority of nonverbal information in the mind. Yoshii (2006) also investigated the effect of pictures on vocabulary learning and found that participants who used definitions in picture format were more successful in tests where definitions are required. Akbulut (2007), in another study, discovered that the groups who had access to two kinds of visual aids along with definitions were more successful than the group which had access to only definitions in vocabulary achievement tests applied just after and sometime after the study. Similarly, Chun and Plass (1996) investigated that the effect of the use of various kinds of multimedia on vocabulary learning. The results indicated that vocabulary presented with written definitions along with pictures helped the participants gain higher scores than those in groups who 
Biçer, D., Akdemir, Ö. (2015). Effective instructional design for web-based English vocabulary learning: Under the light of theories. International Journal of Human Sciences, 12(1), 1463-1476. doi: 10.14687/ijhs.v12i1.3204

had access to definitions in word and video or only in text format. Supporting the use of text and pictures together, another study conducted by Kost, Foss and Lenzini (1999) investigated the effect of vocabulary definitions in mother tongue, pictorial explanations and the use of definitions in the mother tongue and pictures together on foreign language learners' vocabulary learning. The performance in the productivity and awareness tests conducted on the given words is higher in participants who used definitions in text format along with pictures. In another study, Yeh and Wang (2003) found that presenting text and pictures at the same time was the most effective way of teaching vocabulary based on the vocabulary achievement test results.

Another important theory concerning the subject is the Cognitive Load Theory (Miller, 1956). According to Chandler and Sweller (1991), the theory is concerned with the manner in which cognitive resources are focused and used during learning and problem solving. Every activity involved in the learning process causes the loading of the memory. As Chandler and Sweller (1991) point out, during the learning process, the cognitive load generated by irrelevant activities can impede skill acquisition. In sum, they hypothesize that presentation techniques frequently result in high levels of extraneous cognitive load that influence the degree to which learning can be facilitated.

Thus, it can be concluded that the use of cognitive capacity has a considerable effect on learning. Chandler and Sweller (1991) state that information should be presented in ways that do not impose a heavy extraneous cognitive load and for this reason; worked examples that require learners to mentally integrate multiple sources of information are ineffective. According to Brünken, Plass and Leutner (2004), if the input is presented audio visually, the student can use the resources of both systems (audio and visual). However, if the information is presented only in visual format, the resources of only visual system can be used. In sum, the use of cognitive resources varies according to the sort of input presented. Each different kind of input uses a different visual resource.

According to, Plass, Chun, Mayer \& Leutner (2003) who studied on the same theory, students with insufficient cognitive resources have to allocate more of their cognitive resources to process visual and verbal resources than students with superior cognitive capabilities. When students with poor cognitive abilities are expected to process pictures along with verbal definitions, their cognitive abilities can be insufficient. Pictorial definitions cause a great deal of cognitive load because the learner has to assign meaning to the pictures.

Another theory focusing on the subject is the Cognitive Theory of Multimedia Learning (Mayer, 1997, 2001). The Cognitive Theory of Multimedia Learning integrates the Dual Coding 
Biçer, D., Akdemir, Ö. (2015). Effective instructional design for web-based English vocabulary learning: Under the light of theories. International Journal of Human Sciences, 12(1), 1463-1476. doi: 10.14687/ijhs.v12i1.3204

Theory (Paivio, 1971) and the Cognitive Load Theory (Miller, 1956) in a way that focuses on presenting information in dual mode without increasing the cognitive load (Kuzu, Akbulut and Sahin, 2007). As Mayer (2000) states, the theory suggests that students learn better from words and pictures than from words alone, since dual presentation of information help students construct verbal and pictorial mental models together and build connections between these models rather than constructing either a verbal or a pictorial mental model. Plass, Moreno and Brünken (2010) suggest techniques that reduce extraneous cognitive overload. They state that multimedia lessons should minimize the amount of extraneous processing - processing that does not support learningand multimedia learning should help the learner to manage essential processing so that it does not overload the learner's cognitive system.

Blachowicz and Fisher (2000) who support this theory, pointed out that blending the teaching of definitions with active process tasks is more effective than teaching in which only definitions are involved. That is, presenting written definitions with different kinds of content enables more effective learning than presenting them only in text format.

In web-based vocabulary learning, the decision on the use of target language is as important as the process of deciding on which multimedia components to use discussed in the light of theories above. Miyasako (2002) compared the effectiveness of multiple vocabulary definitions and single definitions and also compared them to definitions presented in the mother tongue and target language. Miyasako concluded that while definitions in the target language are more suitable for students with an advanced level of English, for intermediate students, definitions in mother tongue are more effective. Similarly, Al-Jabri (2009) investigated the effect of vocabulary definitions presented in various ways on reading comprehension and recalling skills. Al-Jabri found that definitions provided in mother tongue are more effective than those presented in the target language according to the results of the reading comprehension test he applied.

Ko (2005) observed the effect of the language in which vocabulary definitions are presented on reading skills. As a result of the qualitative analysis, the researcher found out that definitions presented in the target language improve the reading skill considerably. On the other hand, by comparing the groups who are presented vocabulary definitions and those who are not presented such definitions, Ko (2005) found out that definitions presented in both languages improve reading skills. Similarly, Jacobs (1994) conducted a study with participants whose mother tongues are English and are learning Spanish as a second language. The test given just after reading indicated that presenting vocabulary definitions in any language is more useful than presenting no definitions. However, no significant difference was observed between definitions presented in the mother 
Biçer, D., Akdemir, Ö. (2015). Effective instructional design for web-based English vocabulary learning: Under the light of theories. International Journal of Human Sciences, 12(1), 1463-1476. doi: 10.14687/ijhs.v12i1.3204

tongue and the target language. Another supporting study conducted by Yoshii (2006) investigated the effect of pictures and definitions on vocabulary learning. There was no significant difference between groups which used definitions in mother tongue and target language. However, the participants who used definitions in picture format were more successful in tests where definitions are required. A relationship was discovered between the use of pictures and language. When pictures are provided, the group which was presented definitions in target language was more successful than the group which was presented definitions in the mother tongue.

Analysis of the studies revealed that web-based vocabulary learning is used as a part of the web-based language learning. The content is delivered in various forms. However, results of the studies are conflicted to guide educators in determining the form/s that the content is delivered for vocabulary learning. Therefore this study was designed to investigate two research questions:

1. Is there any difference on student vocabulary learning among the content forms used in the web-based vocabulary learning environment?

2. Is there any difference between the use of target or native language on students' vocabulary learning in the web-based vocabulary learning environment?

\section{Method}

\subsection{Context}

The study was conducted at the Compulsory Preparatory Program of the State University located in the Black Sea region. The students, in this program, attend grammar and skill lessons to acquire a sufficient level of English required for their undergraduate education. At the end of an academic year, the students are expected to reach B1 level in European Language Portfolio "Global Scale"

\subsection{Participants}

The study was carried out on 106 students at a Foreign Languages Preparatory Program of the State University in the Spring semester. 56 participants were girls and 50 of them were boys. Seven classes whose levels of English are in the same level were selected for the study. In the process of selecting the sample, students' exam scores were reviewed. It was found out that there was no significant difference in the scores of vocabulary sections, which could affect the results of the study. 
Biçer, D., Akdemir, Ö. (2015). Effective instructional design for web-based English vocabulary learning: Under the light of theories. International Journal of Human Sciences, 12(1), 1463-1476. doi: 10.14687/ijhs.v12i1.3204

\subsection{Research Design}

One of the semi-experimental research designs, the factorial research design (Creswell, 2002) was used in the study. The effect of using multiple forms of the content in web-based instruction on students' English vocabulary learning was analyzed in multiple experimental conditions by applying the factorial research design. Seven experimental conditions designed are presented at the Table 1.

Table 1. Experimental Conditions

\begin{tabular}{ll}
\hline Groups & The Content Form \\
\hline Study Group A & Vocabulary definitions in native language \\
Study Group B & Vocabulary definitions in target language (English) \\
Study Group C & Vocabulary definitions in English accompanied with picture \\
Study Group D & Pictures used to describe vocabularies \\
Study Group E & Audio in native language for vocabulary definitions \\
Study Group F & Audio in target language (English) for vocabulary definitions \\
Study Group G & Audio in English accompanied with pictures for vocabulary definitions \\
\hline
\end{tabular}

In the study, the seven different types of web-based vocabulary lessons were assigned randomly to the seven classes selected for the study.

\subsection{Data Collection Instrument}

An online multiple choice vocabulary test was developed by the researcher as the data collection instrument of the study. The multiple-choice English vocabulary test was applied as a pre and post-test in order to measure students' English vocabulary levels. The content of the test was parallel to the web-based vocabulary lessons and also it was parallel to the coursebook the students used. Thus, content validity was attained. The participants were given 60 minutes to complete the test. In order to attain the internal consistency of the test, it was applied on 50 students identical to the study participants prior to the study. The data obtained were analyzed using the ITEMAN (An Item Analysis Program for Test) software. As a result of the item analysis conducted, the internal consistency of the test was found 0.966 after the items whose Point Biserial values under 0.3 were eliminated. As a result of the analysis, 17 questions were excluded from the test and the final version of the test had 79 questions. Three instructors were consulted in order to attain the validity of the test. Upon getting their feedback and approval, the final version of the test was used in the study.

\section{Findings}

\subsection{Analysis}

Initially the pre-test and the post-test results of the participants were scored. Participants received "1" point for each correct answer and got "0" point for each wrong answer or the unanswered question from the multiple-choice English vocabulary test. These scores ranged from "0" to "79". 
Biçer, D., Akdemir, Ö. (2015). Effective instructional design for web-based English vocabulary learning: Under the light of theories. International Journal of Human Sciences, 12(1), 1463-1476. doi: $10.14687 /$ ijhs.v12i1.3204

After scoring, participants' pre-test and post-test scores were ported into the SPSS version 13.0 for further analysis. Descriptive analysis and the One-way ANOVA were conducted to investigate the research question.

\subsection{Findings}

The descriptive analysis of the pre-test, post-test and the gain scores of participants are presented in the Table 2 .

Table 2. The Descriptive Analysis of the Pre-test and the Post-test Results of Participants

\begin{tabular}{|c|c|c|c|c|c|}
\hline & & $\mathrm{N}$ & Mean & $\begin{array}{c}\text { Std. } \\
\text { Deviation }\end{array}$ & $\begin{array}{l}\text { Mean of } \\
\text { Std. Error }\end{array}$ \\
\hline \multirow{7}{*}{$\begin{array}{l}\text { Pre-Test } \\
\text { Scores }\end{array}$} & Study Group A & 15 & 42.20 & 12.66 & 3.29 \\
\hline & Study Group B & 11 & 34.81 & 18.02 & 3.77 \\
\hline & Study Group C & 16 & 37.93 & 15.00 & 3.03 \\
\hline & Study Group D & 17 & 43.29 & 12.65 & 2.92 \\
\hline & Study Group E & 15 & 38.40 & 9.99 & 3.11 \\
\hline & Study Group F & 18 & 29.16 & 8.31 & 2.85 \\
\hline & Study Group G & 14 & 45.57 & 9.18 & 3.25 \\
\hline \multirow{7}{*}{$\begin{array}{l}\text { Post- } \\
\text { Test } \\
\text { Scores }\end{array}$} & Study Group A & 15 & 61.26 & 12.06 & 4.01 \\
\hline & Study Group B & 11 & 53.27 & 19.97 & 4.59 \\
\hline & Study Group C & 16 & 48.68 & 15.69 & 3.69 \\
\hline & Study Group D & 17 & 56.23 & 15.73 & 3.56 \\
\hline & Study Group E & 15 & 49.00 & 14.36 & 3.79 \\
\hline & Study Group F & 18 & 53.33 & 19.60 & 3.48 \\
\hline & Study Group G & 14 & 52.85 & 12.10 & 3.96 \\
\hline \multirow{7}{*}{$\begin{array}{l}\text { Gain } \\
\text { Scores }\end{array}$} & Study Group A & 15 & 19.06 & 13.62 & 3.30 \\
\hline & Study Group B & 11 & 18.45 & 14.12 & 3.78 \\
\hline & Study Group C & 16 & 10.75 & 11.26 & 3.04 \\
\hline & Study Group D & 17 & 12.94 & 11.35 & 2.93 \\
\hline & Study Group E & 15 & 10.60 & 9.73 & 3.12 \\
\hline & Study Group F & 18 & 24.16 & 16.34 & 2.86 \\
\hline & Study Group G & 14 & 7.28 & 11.56 & 3.26 \\
\hline
\end{tabular}

The first research question investigated whether there was a difference among the English vocabulary learning level of students who completed the web-based instruction provided in a multiple content forms. The last research question investigated that whether there is any difference between the use of target or native language on students' vocabulary learning in the web-based vocabulary learning environment. The results of the One-way ANOVA revealed that the vocabulary achievement levels of the students varied in accordance with the form used to present the content in the web-based instruction $(\mathrm{F}(6,99)=3.44 ; \mathrm{p}<0.05)$ (Table 3). The Scheffe test was applied on the gain scores of the pre-test and the post-test to compare groups. 
Biçer, D., Akdemir, Ö. (2015). Effective instructional design for web-based English vocabulary learning: Under the light of theories. International Journal of Human Sciences, 12(1), 1463-1476. doi: 10.14687/ijhs.v12i1.3204

Table 3. The Pre-Post Test Comparison of the Experiment Groups

\begin{tabular}{lccccc}
\hline Source of Variance & $\begin{array}{c}\text { Sum of } \\
\text { Squares }\end{array}$ & df & $\begin{array}{c}\text { Mean } \\
\text { Square }\end{array}$ & F & p \\
\hline Between Groups & 3374.84 & 6 & 562.47 & 3.445 & 0.004 \\
Within Groups & 16164.55 & 99 & 163.27 & & \\
Sum & 19539.40 & 105 & & & \\
\hline
\end{tabular}

The results of the data analysis revealed that, for the sample of the study composed of students at the same level according to pre-test scores:

Using vocabulary definitions in a sound format is more effective than using vocabulary definitions in a sound format accompanied with picture in teaching English vocabulary in the webbased vocabulary learning environment (Table 4).

Table 4. The Results of Scheffe Test on the Gain Scores of the Participants

\begin{tabular}{lcccccc}
\hline Source of Variance & $\begin{array}{c}\text { Sum of } \\
\text { Squares }\end{array}$ & df & $\begin{array}{c}\text { Mean } \\
\text { Square }\end{array}$ & F & p & $\begin{array}{c}\text { Significant } \\
\text { Difference }\end{array}$ \\
\hline Between Groups & 3374.84 & 6 & 562.47 & \multirow{2}{*}{3.445} & 0.004 & F-G \\
Within Groups & 16164.55 & 99 & 163.27 & & & \\
Sum & 19539.40 & 105 & & & & \\
\hline
\end{tabular}

Table 5. The Results of Scheffe Test on the Gain Scores of F Group and other Groups

\begin{tabular}{ccccccc}
\hline \multirow{2}{*}{ (I) Group } & (J) Group & $\begin{array}{c}\text { Mean } \\
\text { Difference } \\
\text { (I-J) }\end{array}$ & $\begin{array}{c}\text { Standard } \\
\text { Error }\end{array}$ & p & \multicolumn{2}{c}{$\%$ Low confidence } \\
interval \\
& Group A & 5.100 & 4.467 & 0.970 & -11.099 & 21.299 \\
\hline & Group B & 5.712 & 4.890 & 0.967 & -12.020 & 23.445 \\
\cline { 2 - 7 } Group F & Group C & 13.416 & 4.390 & 0.168 & -2.503 & 29.337 \\
\cline { 2 - 7 } & Group D & 11.225 & 4.321 & 0.354 & -4.445 & 26.896 \\
\cline { 2 - 7 } & Group E & 13.566 & 4.467 & 0.174 & -2.632 & 29.765 \\
\cline { 2 - 7 } & Group G & 16.880 & 4.553 & $0.041 *$ & 0.369 & 33.392 \\
\hline
\end{tabular}

$* \mathrm{p}<0.05$

As seen in Tables 4 and 5 , there is significant difference between the vocabulary achievement test results of $F$ group and $G$ group. There is no significant difference between the vocabulary achievement test results of the other groups in which multiple forms of multimedia are used in the study.

Using the target language or the native language for vocabulary definitions have identical effects on students' vocabulary learning in the web-based vocabulary learning environment. 
Biçer, D., Akdemir, Ö. (2015). Effective instructional design for web-based English vocabulary learning: Under the light of theories. International Journal of Human Sciences, 12(1), 1463-1476. doi: 10.14687/ijhs.v12i1.3204

\section{Discussion and Results}

\subsection{Implications}

The results of the study have practical and theoretical implications. On the practical side, this study provides implications for the design of the web-based instruction for English vocabulary learning. In particular, findings suggest that instructional designers and educators should prefer to use audio in target language rather than audio with pictures in target language in the web-based instruction for vocabulary learning. In this study, when the web-based instruction had only audio, students learned more vocabulary than the web-based instruction having audio with pictures. Also it was found that other content forms listed in the research design section of this study have similar effects on students' vocabulary learning. Therefore instructional designers and educators can prefer and use one of the content form listed in the research design section in their web-based instruction for vocabulary learning.

Another important implication of the study for practice is that the use of the mother tongue or the target language in web-based instruction in a text format and in an audio format does not produce different results on students' vocabulary learning. In particular, this finding suggests that either target language or the mother tongue can be selected and used in the web-based instruction for vocabulary learning to obtain similar learning outcomes.

Besides practical ones, the present study also provides theoretical implications. Findings of the study provide evidence supporting the cognitive load theory (Miller, 1956). According to the theory, heavier cognitive load is likely to cause worse performance, in students with lower cognitive abilities. Similarly, it was found that students' vocabulary learning is affected negatively when audio with pictures used in the web-based instruction as compared to the web-based instruction having only audio. Supporting this finding, Chandler and Sweller (1991) stated that worked examples that require learners to mentally integrate multiple sources of information are ineffective. However, results of this study also indicated that students' vocabulary learning is not different in a condition where the text and the text with pictures are used in the web-based instruction. This result is contradicted with the assumption of the cognitive load theory (Miller, 1956). Reaching such a contradicted finding can be the result of the difference in the amount of cognitive load imposed by the text and by the audio. The use of audio in the instruction appears to produce more cognitive load than the use of text. It is open to the question that whether audio and text generate different cognitive load on learners. Such investigation and the findings of this study can be combined to provide evidence for the Cognitive Theory of Multimedia Learning (Mayer, 1997) which focuses on presenting information in dual mode without increasing the cognitive load (Kuzu, Akbulut and 
Biçer, D., Akdemir, Ö. (2015). Effective instructional design for web-based English vocabulary learning: Under the light of theories. International Journal of Human Sciences, 12(1), 1463-1476. doi: 10.14687/ijhs.v12i1.3204

Sahin, 2007). However, in this study it was not possible, probably because dual representation could have caused more cognitive load on learners who just started learning English than they could process effectively.

Another interpretation of the finding that students' vocabulary learning is not different in a condition where the text and the text with pictures are used in the web-based instruction is that participants' cognitive abilities may not be high enough to process the information presented in a text format and in a text format accompanied with pictures. As suggested Plass et al. (2003) who investigated the Cognitive Load Theory, students with lower cognitive ability have difficulty to process pictures along with verbal definitions. In accordance with the theory, similar results have arisen in our study because written text and pictures could have caused heavy cognitive load on students, which hinders learning according to Cognitive Load Theory (Miller, 1956). Besides, it could be due to the fact that the participants were in their first year of learning a foreign language and they were low intermediate learners. However Akbulut (2007)'s finding does not support this proclaim because, in his study, he worked on the freshman students at English teaching department whose levels of English were advanced. Akbulut (2007) found out that the use of visual aids along with definitions turned out to be more successful than aids using only the definitions. Participants' levels of English are at the Advanced level in Akbulut (2007)'s study while Participants' levels of English are at the low-Intermediate level in this study. Therefore the difficulty of the vocabulary used in the study and the relationship between the foreign language levels of students may have resulted in inconsistencies in the results.

\subsection{Future Work}

The use of computer technologies and the internet has become quite widespread recently in the field of vocabulary teaching. As any computer technology, web-based instruction requires the use of certain content and software. However, the decision on what sort of content to use on certain student groups is important. In our study, the quantitative data were gathered from the participants who used the different web-based vocabulary lessons. Further research may focus on the use of qualitative research methods which would present a more thorough picture of effectiveness of the methods used for the web-based English vocabulary learning which have the potential to illuminate the underlying assumptions of Multimedia theories. In further studies, the pre-tests can be developed in a more detailed way, aiming to measure students' both level of cognitive abilities and personal preferences in vocabulary learning. Also, the learning styles of the students can be determined and taken into account. Also mobile devices which are popular among teenagers and eliminate the time and distance limitations can be used in future studies to investigate 
Biçer, D., Akdemir, Ö. (2015). Effective instructional design for web-based English vocabulary learning: Under the light of theories. International Journal of Human Sciences, 12(1), 1463-1476. doi: 10.14687/ijhs.v12i1.3204

effects of the web-based instruction on vocabulary learning when mobile devices are used for connections.

\section{References}

Akbulut, Y. (2007). Effects of multimedia annotations on incidental vocabulary learning and reading comprehension of advanced learners of English as a foreign language. Instructional Sciences, 35, 499-517.

Akdemir, Ö. (2008). Online Courses: Experiences of Instructional Technology Faculty Members. Turkish Online Journal of Distance Education-TOJDE, 9, 2, 97-108.

Al-Jabri, S. S. (2009). The Effects of L1 and L2 Glosses on Reading Comprehension and Recalling Ideas by Saudi Students. Umm Al-Qura University Journal of Social Sciences, 1, 1, 11-27.

Basoglu, E. B. \& Akdemir, Ö. (2010). A Comparison of Undergraduate Students' English Vocabulary Learning: Using Mobile Phones and Flash Cards. TOJET: The Turkish Online Journal of Educational Technology, 9, 3, 1-7.

Blachowicz, C. L. Z. \& Fisher P. J. L. R. Barr, M. L. Kamil, P. B. Mosenthal, \& P. D. Pearson (Eds.). (2000). Vocabulary instruction. Handbook of reading research. New York: Longman.

Brünken, R., Plass, J.L. \& Leutner D. (2004). Assessment of Cognitive Load in Multimedia Learning with Dual-Task Methodology: Auditory Load and Modality Effects. Instructional Science, 32, 115-132.

Chandler, P. \& Sweller, J. (1991). Cognitive Load Theory and the Format of Instruction. Cognition and Instruction, 8, 293-332.

Chun, D. M. \& Plass, J. L. (1996). Effects of multimedia annotations on vocabulary acquisition. The Modern Language Journal, 80, 183-198.

Creswell, John W. (2002). Research Design: Qualitative, Quantitative, and Mixed Methods Approaches, U.S.A: SAGE Publications

Hamatr, A. (2008). Web Technologies for Language Learning and Implications for the design of CMS or language instructon. Proceedins of World Academy of Science, Engineering and Technology, 29, 61-65.

Hismanoglu, S. (2010). Focus on Vocabulary. Procedia Social and Behavioral Sciences, 3, 106-111.

Iandoli, L. J. (1990). Call and the Profession: The current state. The French Review, 64, 2, 261-272.

Karal, H. \& Berigel, M. (2007). Yabancı Dil Eğitim Ortamlanının Bilisim ve İletisim Teknolojileri Kullanılarak Zenginlestirilmesi. [http://inet-tr.org.tr/inetconf11/bildiri/56.doc], Retrieved: 22.01.2011.

Ko, M. H. (2005). Glosses, comprehension, and strategy use. Reading in a Foreign Language, 17, 2.

Kost, C. R., Foss, P., \& Lenzini, J. L. (1999). Textual and Pictorial Glosses: Effectiveness on Incidental Vocabulary Growth When Reading - in a Foreign Language. Foreign Language Annals, 32, 1, 89-97.

Kuzu, A., Akbulut, Y. \& Sahin M. C. (2007). Application of Multimedia Design Used in Course-Books: An Evaluation Tool. The Turkish Online Journal of Educational Technology, 6, 2, 8-14.

Ma, Q. \& Kelly, P. (2006). Computer Assisted Vocabulary learning: Design and Evaluation. Computer Assisted Language Learning, 19, 1, 15-45.

Mayer, R. E. (1997). Multimedia learning: Are we asking the right questions? Educational Psychologist, 32, 119.

Mayer, R. E. (2000). Multimedia Learning, Cambridge: Cambridge University Press.

Mayer, R.E. (2001). Multimedia Learning. New York: Cambridge University Press.

Miller, G. A. (1956). The Magical Number Seven or Minus Two: Some Limits on our Capacity for Processing Information. Psychological Review, 63, 81-97.

Miyasako, N. (2002). Does text-glossing have any effects on incidental vocabulary learning through reading for Japanese senior high school students? Language Education \& Technology, 39, 1-20.

Paivio, A.(1971). Imagery and verbal processes. New York: Holt, Rinehart, Winston.

Paivio, A.(1990). Mental Representations: A Dual Coding Approach. Oxford: Oxford University Press. 
Biçer, D., Akdemir, Ö. (2015). Effective instructional design for web-based English vocabulary learning: Under the light of theories. International Journal of Human Sciences, 12(1), 1463-1476. doi: 10.14687/ijhs.v12i1.3204

Paivio, A. \& Csapo, K. (1973). Picture Superiority in Free Recall: Imagery or Dual Coding?. Cognitive Psychology, 5, 176-206.

Plass, J. L., Chun D. M., Mayer, R. E., \& Leutner, D. (2003). Cognitive load in reading a foreign language text with multimedia aids and the influence of verbal and spatial abilities. Computers in Human Behavior, 19, 221-243.

Plass, J. L., Moreno R., \& Brünken, R. (2010). Cognitive Load Theory, Cambridge, UK: Cambridge University Press.

Sarıca, G. N. \& Çavus, N. (2009). New trends in 21st Century English learning. Procedia Social and Behavioral Sciences, 1, 439-445.

Simsek, A., Özdamar, N., Becit, G., Kılıçer, K., Akbulut, Y., \& Yıldırım, Y. (2007). Türkiye'de Eğitim Teknolojileri Arasturmalarında Güncel Eğilimler. Presented at 1st International Computer and Instruction Technologies Symposium, Çanakkale, Turkey.

Türkyılmaz, M. (2008). Dil ve Anlatım Dersinde Bir Ölçme Aracı Olarak Yazılı Sınavlanın Kullanımı Konusunda Öğretmen Görüsleri. Ahi Evran Üniversitesi Kırsehir Eğitim Fakültesi Dergisi (KEFAD), 9, 3, 1-14.

Wood, J. (2001). Can software support children's vocabulary development? Language Learning \& Technology, 5, 1, 66-201.

Yeh, Y. \& Wang, C. W. (2003). Effects of Multimedia Vocabulary Annotations and Learning Styles on Vocabulary Learning. CALICO Journal, 21, 1, 131-144.

Ying Ping, Chen (2008); "Foreign language learning based on Knowledge Building Pedagogy and webresources," US-China Foreign Language, 6, 3, 22-32.

Yoshii, M. (2006). L1 and L2 glosses: Their Effects on Incidental Vocabulary Learning. Language Learning \& Technology, 10, 3, 85-101.

Zhang, C. (2009). Mental lexicon and English Vocabulary Teaching. US-China Foreign Language, 7, 3, 4245. 